\title{
GALLIC ACID PRODUCTION AND TANNASE ACTIVITY OF PENICILLIUM PURPUROGENUM STOLL EMPLOYING AGROBASED WASTES THROUGH SOLID STATE FERMENTATION : INFLUENCE OF CARBON AND NITROGEN SOURCES.
}

\author{
S. BHASKAR REDDY and VANDANA RATHOD* \\ *Department of Microbiology, Gulbarga University, Gulbarga 585106.
}

\begin{abstract}
The influence of various carbon sources and nitrogen sources on tannase and gallic acid production in SSF by $P$. purpurogenum BVG7 was studied. Sugars were beneficial only up to $0.2 \%$ concentrations and higher levels inhibited tannase and gallic acid production. Amongst the various $\mathrm{N}$ compounds $\left(\mathrm{NH}_{4} \mathrm{NO}_{3}, \mathrm{NH}_{4} \mathrm{Cl}, \mathrm{NaNO}_{3}\right.$, and $\left.\mathrm{KNO}_{3}\right)$ supplemented to the substrates, $\mathrm{NH}_{4} \mathrm{NO}_{3}$ even at much lower concentration was the most beneficial even at lower concentrations than others for gallic acid production.
\end{abstract}

\section{INTRODUCTION}

Use of microorganisms for producing gallic acid through suspended solid and submerged fermentations has been of late receiving more attention since the product finds wide applications in pharmaceutical and chemical industries due to its varied biological activities (antioxidant, anti-apoptotic, antibacterial, antiviral, analgesic etc.) and also being precursor of trimethoprim, propyl gallate and some dyes (Pourrat et al., 1987; Mondal, 2001). Gallic acid production through the mediation of tannase enzyme of microbial origin through either SmF or SSF utilizes the agrobased wastes, thereby reducing environmental pollution as well as harnessing wealth from waste. Solid state fermentation is considered to be more advantageous over the submerged fermentation (Aguilar et al., 2001). Adapting SSF necessitates the process of optimization of fermentation parameters including physico-chemical parameters. Once the basic fermentation parameters like fermentation period, moisture content, inoculum size, substrate concentration, $p \mathrm{H}$, and temperature are optimized, it becomes necessary to attempt increases in product yields. Since the agrobased wastes are generally ill-defined substrates, supplementation of various carbon and nitrogen sources, other organic substances like fatty acids, alcohols, acids, vitamins etc., have proved to be beneficial in achieving higher product yields. The present report deals with the evaluation of influence of certain $\mathrm{C}$ and $\mathrm{N}$ sources on tannase and gallic acid production by Penicillium purpurogenum BVG7 from agrobased wastes like Acacia pods, redgram husk, sorghum husk and spent tea powder through SSF.

\section{MATERIALS AND METHODS}

The fungal strain, $P$. purpurogenum BVG7, was isolated from the soil samples in the vicinity of leather industries, agricultural fields and cobbler's places and maintained on $2 \%$ malt extract slants at $32^{\circ} \mathrm{C}$. The slants were subcultured routinely at an interval of 4-5 weeks and the freshly grown slant cultures were used for the experimental studies. The substrates used in the present study were Acacia pods, redgram husk, sorghum husk and spent tea powder. Each substrate was dried, finely powdered in a mixer mechanically and then $15 \mathrm{~g}$ of each substrate was taken in a $50 \mathrm{ml}$ Ehrlenmeyer flask. The initial culture conditions maintained were moisture level of $70 \%, p \mathrm{H} \mathrm{5.5}$, and inoculation with $4 \mathrm{ml}$ inoculum $\left(2 \times 10^{7}\right.$ spores $/ \mathrm{ml}$ ) and incubated at $30^{\circ} \mathrm{C}$ for $96 \mathrm{hr}$. In the studies involving the influence of carbon sources on the process of tannase and gallic acid production, glucose, fructose, lactose and sucrose were separately added to each substrate in the varying concentrations of $0.01,0.05,0.1,0.2, .05,1.0,3.0$, and $5.0 \mathrm{~g} / 100 \mathrm{~g}$ substrate. In the studies pertaining to the influence of nitrogenous compounds, ammonium nitrate, ammonium chloride, sodium nitrate and potassium nitrate were separately added to each substrate in varying concentrations of 250, 500, 750, 1000, 1500 and $2000 \mathrm{mg} / 100 \mathrm{~g}$ substrate. Suitable controls

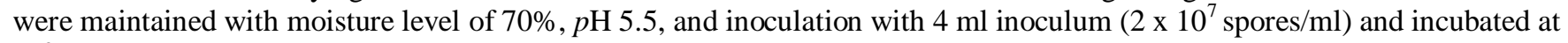
$30^{\circ} \mathrm{C}$ for $96 \mathrm{hr}$ for each substrate. The results are the mean of five replicates.

Tannic acid estimation was as done per the protein precipitation method of Haggerman and Butler (1978) employing bovine serum albumin (BSA) as the standard protein. Tannic acid content of the substrates and the fermentation medium were 
estimated as per Ibuchi et al. (1967) and the per cent yield of gallic acid was calculated based on the estimation of available tannic acid in the fermented medium.

\section{RESULTS}

The results on the influence of sugar supplementation in different concentrations to the four substrates on tannase activity and gallic acid production of $P$. purpurogenum is presented in Fig. 1 and 2, taking the example of glucose supplemenatation. Tannase activity and gallic acid production tended to increase gradually up to $0.2 \mathrm{~g}$ glucose $/ 100 \mathrm{~g}$ substrate, while higher supplementations of glucose sharply decreased both the enzyme activity and acid production. At $5.0 \mathrm{~g}$ glucose level, enzyme activity and gallic acid production were almost inhibited. Same trend was observed in all the substrates. Enzyme activity and gallic acid production were maximal in Acacia pods, followed by redgram husk and sorghum husk, the least being in the spent tea powder. The supplementation of lactose and sucrose also led to similar observations, maximum tannase activity and gallic acid production being recorded at $0.2 \mathrm{~g} / 100 \mathrm{~g}$ substrate. Only in case of fructose, higher level of fructose supplementation ( $0.5 \mathrm{~g}$ fructose $/ 100 \mathrm{~g}$ substrate) was necessary to yield maximum enzyme and acid production (Tables 1 and 2). Higher levels of fructose additions sharply decreased the enzyme activity and acid production, as in case of other sugars.

The results on the influence of nitrogen supplementation in different concentrations to the four substrates on tannase activity and gallic acid production of $P$. purpurogenum are presented in Fig. 3 and 4, taking example of $\mathrm{NH}_{4} \mathrm{NO}_{3}$ addition. Tannase and gallic acid production tended to increase up to $500 \mathrm{mg} \mathrm{NH}_{4} \mathrm{NO}_{3} / 100 \mathrm{~g}$ substrate, while higher supplementations of the

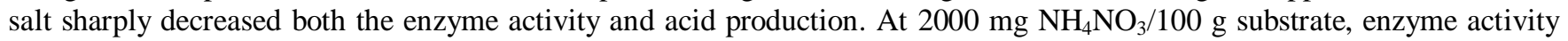
and gallic acid production were almost inhibited. Similar trend was observed in all the substrates. Enzyme activity and gallic acid production were maximal in Acacia pods, followed by redgram husk and sorghum husk, the least being in the spent tea powder. The supplementation of $\mathrm{NaNO}_{3}$ and $\mathrm{KNO}_{3}$ also led to similar observations, maximum tannase activity and gallic acid production being recorded at $1000 \mathrm{mg} / 100 \mathrm{~g}$ substrate. But in sorghum husk, higher level $(1500 \mathrm{mg} / 100 \mathrm{~g}$ substrate) of $\mathrm{NH}_{4} \mathrm{Cl}_{4}$ was required to effect maximum enzyme activity and acid production. Only in case of $\mathrm{NH}_{4} \mathrm{NO}_{3}$, a lower level of 500 $\mathrm{mg} / 100 \mathrm{~g}$ substrate was required to cause maximum enzyme and acid productions (Tables 3 and 4).

\section{DISCUSSION}

The present study indicates that amongst the various sugars, glucose was the most beneficial sugar for the production of tannase activity and gallic acid production by $P$. purpurogenum BVG7. The next beneficial sugar was lactose, with fructose closely following and sucrose the least. All sugars were beneficial only up to concentrations of $0.2 \mathrm{~g} / 100 \mathrm{~g}$ substrate and thereafter in their higher concentrations, enzyme activity and gallic acid production tended to decrease sharply (Table 1 and 2). Earlier workers (Hadi et al., 1994; Aguilar et al., 2001a; Van de Lagemaat and Pyle, 2001; Fumihiko and Kiyoshi, 1975) had employed 0.06 to $7.0 \%$ glucose and sucrose to promote tannase production by various fungal species and reported that excepting glucose other sugars had no beneficial effects on the activities and hence, glucose appeared to be the most favored of the sugars. Lekha and Lonsane (1997) too reported that the presence of other readily utilizable carbon sources did not enhance tannase production of $A$. niger PKL 104. The decrease in tannase and gallic acid production by higher concentrations of sugars appear to be due to the osmotic stress (Bradoo et al., 1977).

The nitrogen sources supplemented to the various substrates in the present study were all equally slightly beneficial to $P$. purpurogenum BVG7 as far as tannase production is concerned (Table 3). But their influence on gallic acid production was more pronounced. $\mathrm{NH}_{4} \mathrm{NO}_{3}$ was most beneficial even at $500 \mathrm{mg} / 100 \mathrm{~g}$ substrate concentration. Other forms of $\mathrm{N}$ sources $\left(\mathrm{NH}_{4} \mathrm{Cl}, \mathrm{NaNO}_{3}\right.$ and $\left.\mathrm{KNO}_{3}\right)$ to were beneficial to the organism under study but considerably at higher levels of $2000 \mathrm{mg} / 100$ $\mathrm{g}$ substrate for gallic acid production (Table 4). Earlier workers reported $\mathrm{NH}_{4} \mathrm{NO}_{3}$ to be a better nitrogen source for tannase production since the fungal species were able to utilize $\mathrm{N}$ from both $\mathrm{NH}_{4}$ and $\mathrm{NO}_{3}$ (Nagib and Saddik, 1960; Bradoo et al., 1997; Lekha and Lonsane, 1997; Shamina Begum, 2006). Battestin and Macedo (2007) too reported that $\mathrm{NH}_{4} \mathrm{NO}_{3} \mathrm{had}$ significant influence on tannase production than $\mathrm{KNO}_{3}$. In the present study too, $\mathrm{NH}_{4} \mathrm{NO}_{3}$ not only stimulated tannase and gallic acid production at lower concentrations but also proved to be more beneficial than other inorganic $\mathrm{N}$ sources.

On the whole it can be concluded that glucose was the most favored $\mathrm{C}$ source and $\mathrm{NH}_{4} \mathrm{NO}_{3}$ was the most favored $\mathrm{N}$ source for the tannase and gallic acid production respectively, by $P$. purpurogenum BVG7 from the various agrobased substrates through suspended solid fermentation. 
Table 1. Influence of $C$ sources on Tannase activity in different substrates in SSF

\begin{tabular}{|l|l|l|l|l|}
\hline $\begin{array}{l}\text { Sugars, } \mathrm{mg} / 100 \mathrm{~g} \\
\text { substrate }\end{array}$ & Acacia pods & Redgram husk & Sorghum husk & Spent tea powder \\
\hline Glucose, $0.2 \mathrm{mg}$ & $46.5 \pm 1.2$ & $44.0 \pm 1.8$ & $43.5 \pm 2.1$ & $38.0 \pm 1.2$ \\
\hline Fructose, $0.2 \mathrm{mg}$ & $43.5 \pm 1.0$ & $43.0 \pm 1.9$ & $42.0 \pm 2.0$ & $35.5 \pm 1.0^{*}$ \\
\hline Lactose, $0.2 \mathrm{mg}$ & $45.5 \pm 2.3$ & $44.0 \pm 1.1$ & $43.7 \pm 2.1$ & $37.5 \pm 1.7$ \\
\hline Sucrose, $0.2 \mathrm{mg}$ & $44.1 \pm 1.0$ & $43.7 \pm 1.7$ & $43.0 \pm 2.3$ & $36.7 \pm 2.0$ \\
\hline Control & $40.5 \pm 1.4$ & $39.0 \pm 1.4$ & $38.5 \pm 2.1$ & $30.0 \pm 1.2$ \\
\hline
\end{tabular}

* at $0.5 \mathrm{mg} / 100 \mathrm{~g}$ substrate

Table 2. Influence of $\mathrm{C}$ sources on Gallic acid production in different substrates in SSF

\begin{tabular}{|l|l|l|l|l|}
\hline $\begin{array}{l}\text { Sugars, } \mathrm{mg} / 100 \mathrm{~g} \\
\text { substrate }\end{array}$ & Acacia pods & Redgram husk & Sorghum husk & Spent tea powder \\
\hline Glucose, $0.2 \mathrm{mg}$ & $85.7 \pm 2.3$ & $83.0 \pm 1.2$ & $82.0 \pm 1.5$ & $78.5 \pm 2.2$ \\
\hline Fructose, $0.2 \mathrm{mg}$ & $79.7 \pm 1.9$ & $77.0 \pm 1.2$ & $75.0 \pm 1.5$ & $65.8 \pm 2.5^{*}$ \\
\hline Lactose, $0.2 \mathrm{mg}$ & $82.7 \pm 1.2$ & $82.0 \pm 1.9$ & $81.0 \pm 2.5$ & $73.5 \pm 2.6$ \\
\hline Sucrose, $0.2 \mathrm{mg}$ & $80.7 \pm 2.5$ & $79.0 \pm 1.2$ & $77.0 \pm 1.9$ & $69.5 \pm 2.0$ \\
\hline Control & $70.7 \pm 1.8$ & $69.0 \pm 1.7$ & $68.4 \pm 1.5$ & $58.5 \pm 2.2$ \\
\hline
\end{tabular}

* at $0.5 \mathrm{mg} / 100 \mathrm{~g}$ substrate

Table 3. Influence of $\mathrm{N}$ sources on Tannase activity in different substrates in SSF

\begin{tabular}{|l|l|l|l|l|}
\hline $\begin{array}{l}\mathrm{mg} / 100 \mathrm{~g} \\
\text { substrate }\end{array}$ & Acacia pods & Redgram husk & Sorghum husk & Spent tea powder \\
\hline $\begin{array}{l}\text { Amm. chloride, } \\
1000 \mathrm{mg}\end{array}$ & $42.5 \pm 1.4$ & $41.0 \pm 1.4$ & $40.5 \pm 1.2 *$ & $36.0 \pm 1.2$ \\
\hline $\begin{array}{l}\text { Amm. Nitrate, } \\
500 \mathrm{mg}\end{array}$ & $41.2 \pm 2.2$ & $40.5 \pm 2.0$ & $40.9 \pm 1.0$ & $36.0 \pm 1.2$ \\
\hline $\begin{array}{l}\text { Sod. nitrate, } \\
1000 \mathrm{mg}\end{array}$ & $42.5 \pm 1.4$ & $41.0 \pm 1.4$ & $40.5 \pm 1.2$ & $36.0 \pm 1.2$ \\
\hline $\begin{array}{l}\text { Pot. nitrate, } \\
1000 \mathrm{mg}\end{array}$ & $43.0 \pm 1.4$ & $41.0 \pm 1.4$ & $39.5 \pm 1.2$ & $36.0 \pm 1.2$ \\
\hline Control & $40.5 \pm 1.4$ & $39.0 \pm 1.4$ & $38.5 \pm 2.1$ & $30.0 \pm 1.2$ \\
\hline
\end{tabular}

* at $1500 \mathrm{mg} / 100 \mathrm{~g}$ substrate 
Table 2. Influence of N sources on Gallic acid production in different substrates in SSF

\begin{tabular}{|l|l|l|l|l|}
\hline $\begin{array}{l}\mathrm{mg} / 100 \mathrm{~g} \\
\text { substrate }\end{array}$ & Acacia pods & Redgram husk & Sorghum husk & Spent tea powder \\
\hline $\begin{array}{l}\text { Amm. chloride, } \\
1000 \mathrm{mg}\end{array}$ & $77.7 \pm 1.8$ & $75.0 \pm 1.7$ & $74.3 \pm 1.9^{*}$ & $62.5 \pm 2.2$ \\
\hline $\begin{array}{l}\text { Amm. Nitrate, } \\
500 \mathrm{mg}\end{array}$ & $75.0 \pm 1.9$ & $77.0 \pm 1.2$ & $75.0 \pm 1.5$ & $65.8 \pm 2.5$ \\
\hline $\begin{array}{l}\text { Sod. nitrate, } \\
1000 \mathrm{mg}\end{array}$ & $73.7 \pm 1.8$ & $71.0 \pm 1.7$ & $70.3 \pm 1.9$ & $62.5 \pm 2.2$ \\
\hline $\begin{array}{l}\text { Pot. nitrate, } \\
1000 \mathrm{mg}\end{array}$ & $74.7 \pm 1.8$ & $69.0 \pm 1.7$ & $67.3 \pm 1.9$ & $60.5 \pm 2.2$ \\
\hline Control & $70.7 \pm 1.8$ & $69.0 \pm 1.7$ & $68.4 \pm 1.5$ & $58.5 \pm 2.2$ \\
\hline
\end{tabular}

* at $1500 \mathrm{mg} / 100 \mathrm{~g}$ substrate

\section{REFERENCES}

1. Aguilar, C. N., Augur, C., Favela-Torres, E., and Viniegra-Gonzalez, G. (2001), Production of tannase by Aspergillus niger As-20 in submerged and solid-state fermentation : Influence of glucose and tannic acid." J. Industrial Microbiol. Biotechnol., 26(5) 296-302.

2. Battestin, V. and Macedo, G. A. (2007) "Tannase production by Paecilomyces varioli." Bioresource Technol., 98(9) 1832-1837.

3. Bradoo, S., Gupta, R., and Saxena, R. K. (1997), "Parametric optimization and biochemical regulation of extracellular tannase from A. japonicus." Process. Biochem., 32(2), 135-139.

4. $\quad$ Fumihiko, Y., and Kiyoshi, M., (1975) Japanese Pat. 72, 25, 786.

5. Hadi, T. A., Banerjee, R., and Bhattacharya, B. C., (1994), "Optimization of tannase biosynthesis by newly isolated Rhizopus oryzae. Bioprocess Engg., 11, 239-243.

6. Haggerman, A. E. and Butler, L. G. (1978), "Protein precipitation method for determination of tannins." J. Agric. Food Chemic., 26, 809-812.

7. Ibuchi, S., Minoda, Y. and Yamada, K. (1967), "Studies on tannin acyl hydrolase of the microorganism: Part III. A new method of determining the enzyme activity using change in the ultraviolet absorption." $J$. Agric. Biol. Chem., 31, 513-518.

8. Lekha, P. K. and Lonsane, B. K. (1997), "Production and application of tannin acyl hydrolase : State of the art." Adv. Appl. Microbiol., 44, 215-260.

9. Nagib, K., and Sadiq, K. (1960), "Growth and metabolism of Aspergillus nidulans Eidam on different nitrogen sources in the synthetic media conducive fat formation. Canadian J. Bot., 38, 613.

10. Shamina Begum (2006), "Production of tannase by Aspergillus terreus using agro-wastes under solid state fermentation." Ph. D. thesis, Gulbarga Univ.

11. Van de Lagemaat, J., and Pyle, D. L. (2001), "Solid state fermentation and bioremediation : Development of a continuous process for the production of fungal tannase." Chemical Engg. J., 84, 115-123. 